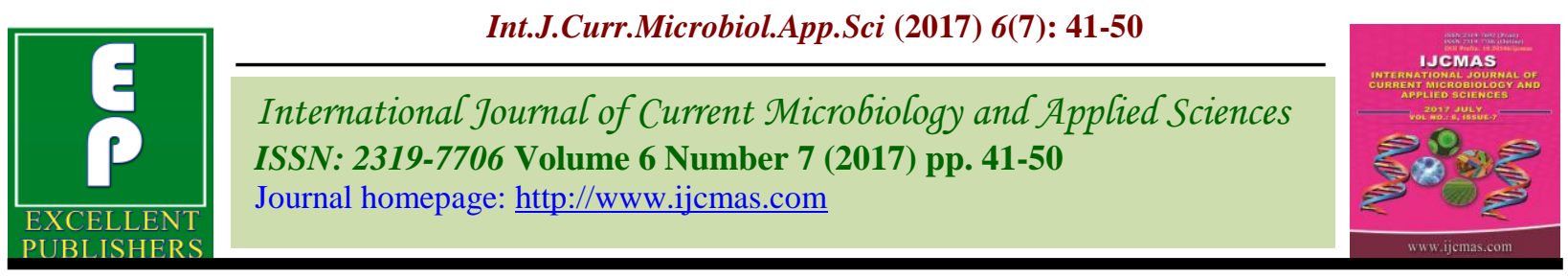

Original Research Article

https://doi.org/10.20546/ijcmas.2017.607.006

\title{
Studies on Bacillus sp, As an Efficient Plant Growth Promoting Rhizobacteria from Taxus wallichiana Zucc. an Endangered Conifer of Kashmir Himalaya
}

\author{
Nazish Nazir ${ }^{1 *}$, Azra N. Kamili1 , M.Y. Zargar ${ }^{4}$, Imran Khan², \\ Durdana Shah ${ }^{1}$, Sumira Tyub ${ }^{1}$ and Rubiya Dar $^{3}$ \\ ${ }^{1}$ Centre of Research for Development, ${ }^{2}$ Department of Environmental Sciences, \\ ${ }^{3}$ Department of Biotechnology, University of Kashmir, Srinagar- 190006, J\&K, India \\ ${ }^{4}$ Sher-e-Kashmir University of Agricultural Sciences and Technology Kashmir, \\ Shalimar Campus, Srinagar- 190025 J\&K, India \\ *Corresponding author
}

\section{A B S T R A C T}

\section{Ke y w ords \\ Bacillus safensis, Bacillus subtilis, Biofertilizer, \\ Himalaya, Taxus wallichiana \\ Article Info \\ Accepted: \\ 04 June 2017 \\ Available Online: \\ 10 July 2017}

The rhizospheric flora plays a vital role in the growth and establishment of the forest trees especially at early stages. Taxus wallichiana, being a slow growing conifer of Kashmir Himalaya, has been studied for isolation and characterization of the growth promoting bacteria from its rhizosphere. Two species of Bacillus namely B. subtilis and B. safensis were isolated and characterized by $16 \mathrm{~S}$ rRNA gene technique. These bacteria have showed effective growth promoting properties like phosphate solubilization and IAA production. During this study both species were found quite effective and reliable sources for use as bio-fertilizer for improving the growth of this endangered forest tree under natural conditions.

\section{Introduction}

Forest ecosystems are highly organized systems of biotic and abiotic components and are both structurally and functionally, linked as a sensitive dynamic equilibrium (Kraigher, 1999). Soil microbial diversity plays a key role in maintaining this dynamic equilibrium along with multi functionality of forests by supporting processes such as litter decomposition and organic matter mineralization (Cardinale et al., 2011) by transferring of matter and energy between above and belowground communities (Jing et al., 2015). Like other forest ecosystems of world, Climate change coupled with population pressure have deteriorated the Himalayan ecosystems too, while the degradation and habitat fragmentation are clearly evident (Shrestha et al., 2012). Over the last century, Northwestern Himalayan forest coverage have showed tremendous decline because of enhanced anthropogenic interferences (Qamer et al., 2016). The decrease in forest area is countered usually by afforestation programmes involving planting of the trees in deforested areas. But there are some major difficulties in successful afforestation programmes because of less percentage of adaptation and acclimatization 
of planted trees. Thus some alternative strategies have to be chalked out that can ensure enhanced growth of tree species in forest ecosystems, which will provide protection and environmental safety in order to maintain long term ecological balance in forest ecosystems. The use of microbial inoculants or Plant Growth Promoting Rhizobacteria (PGPR) for the enhancement of sustainable forestry production is one such alternative which has been widely accepted and used in many parts of the world (Majeed et al., 2015).

Taxus wallichiana, an evergreen medium sized conifer growing in Kashmir Himalaya (Thomas, 2011), has been over exploited owing to its durable and strong nature of wood as well as medicinal value (Rahman et al., 2013). Presence of "taxol" in its shoots and leaves has shown an exciting potential as an anti-cancer drug, particularly in the treatment of ovarian cancers (Gholami et al., 2014). Due to its medicinal properties and other commercial values there is increased pressure on the natural populations of this plant.

The over exploitation coupled with poor natural regeneration potential, has led to the tremendous decrease in its populations (Sharma and Uniyal, 2010). So the need of the hour is to regenerate its population in nature by planting the seedlings in the natural environment. In this regard, like other afforestation programmes use of PGPRs can be used for establishment of Taxus walliachiana especially during early stages. Thus, to meet the challenge, present study on the PGPRs of $T$. wallichiana was carried out. The present work emphasizes the role of predominant Bacillus species because of their ability of forming resistant endospores and also these have been reported to promote plant growth by indirectly affecting symbiotic $\mathrm{N}_{2}$ fixation, nodule occupancy (Amin et al.,
2015). Hence the main objective of the present study was to isolate the potential Bacillus species from the rhizospheric soil of T. wallichiana for using these isolates as PGPR inoculant in order to find an alternative strategy to chemical fertilizers for its sustainable growth and development.

\section{Materials and Methods}

\section{Study area}

Present study was undertaken in the Tangmarg forest area of Kashmir Himalaya. It is located at latitude $34^{\circ} 03^{\prime} 40.8^{\prime \prime} \mathrm{N}$ and longitude $74^{\circ} 25^{\prime} 35.4^{\prime \prime} \mathrm{N}$ and an elevation of $2128 \mathrm{~m}$ above the sea level in the District Baramulla of J\&K, India. The dominant forest vegetation is mainly represented by Pinus walliachaina in lower altitudes (1650-2500 masl) and by Abies pindrow and Picea smithiana at higher altitudes (2300-3300 masl). The topography is mainly hilly and mountainous with stretches of plains and valleys in between. The area is characterized by temperate climatic conditions with four distinct seasons. The monthly mean temperature ranges from a minimum of $-4^{\circ} \mathrm{C}$ to a maximum of $32.5^{\circ} \mathrm{C}$ accompanied by a severe cold and snow fall in winter. For the present study three sites were selected at a distance of around $1 \mathrm{~km}$ within sites (Figure 1).

\section{Collection of rhizospheric soil}

The rhizospheric soil samples of Taxus wallichiana were collected from three selected sites in the months of June-August 2014. Rhizospheric soil was shaken from the roots and collected in sterilized plastic ziplock bags and was brought to Microbiology laboratory of the Centre of Research for Development (CORD), University of Kashmir for immediate processing. 


\section{Isolation of rhizobacteria}

Rhizobacteria were isolated from $1 \mathrm{~g}$ of soil tightly adhering to the root by serial dilution plating Luria-Bertani (LB) agar plates as described by Parray et al., (2015). The plates were incubated at $28 \pm 2^{\circ} \mathrm{C}$ till the appearance of bacterial colonies. Individual colonies were picked and streaked on LB plates for further purification. A total of twelve isolates were obtained in this manner and were maintained on agar slants and stored at $4^{\circ} \mathrm{C}$ for further processing.

\section{Characterization of isolates}

The isolates were characterized on the basis of morphology using Bergey's Manual of Systematic Bacteriology (Bergey et al., 1986) and by performing Gram's staining to know whether the isolates were gram positive or gram negative. The isolates were observed under the light microscope to obtain the colony morphology and cell shape. Various carbohydrate utilizing tests like citrate, arginine, sucrose, mannitol, glucose, arabinose and trehalose for biochemical characterization were subjected to biochemical tests using strain specific biochemical kits (Hi-media), separately for Gram positive and Gram negative strains. The strains were identified as per the chart sheet of the kits to the nearest value. Pure cultures of the isolates were stored at $-20^{\circ} \mathrm{C}$ in nutrient broth supplemented with $200 \mathrm{mg} / \mathrm{g}$ glycerol, for the screening of growth promoting activities.

\section{Bioassays for plant growth promoting characteristics of rhizobacterial isolates}

All the twelve bacterial isolates were subjected to various Plant Growth Promoting characteristics. Out of which only two isolates TR5 and TR7 showed the efficiency to produce all the essential PGP traits.
The amount of soluble phosphate of the bacterial isolates was measured by the colorimetric method as described by King (1959). Quantitative estimation of IAA production was detected as described by Brick et al., (1991). HCN and Ammonia production was done using Castric's method (Castric, 1975) and as described by Cappucino and Sherman (1992) respectively. The catalase production was checked by placing a drop of $\mathrm{H}_{2} \mathrm{O}_{2}$ onto the bacterial colony on a glass slide as described by Schaad (1992). These two potential isolates (TR5 and TR7) were subjected for identification as per $16 \mathrm{~S}$ rRNA gene sequencing.

\section{Identification of isolates as per $16 \mathrm{~S}$ rRNA gene partial sequencing}

Total genomic DNA of two bacterial isolates was extracted using HiPurATM Bacterial Genomic DNA Purification Kit (HIMEDIA MB505-50PR). Amplification of 16S rRNA gene using universal bacterial primers 27F (5'-AGAGTTTGATCCTGGCTCAG-3') and 1429R (5'-GGTTACCTTGTTACGACTT-3') (Sujatha et al., 2012), was carried out in a $50 \mu \mathrm{PCR}$ reaction mixture containing miliQ $(33.4 \mu \mathrm{l})$, dNTPs $(5 \mu \mathrm{l})$, Taq buffer $(5 \mu \mathrm{l})$, FP $(1 \mu l)$, RP $(1 \mu \mathrm{l})$, DNA Template $(4 \mu \mathrm{l})$, Taq Polymerase $(0.5 \mu \mathrm{l})$. Amplification was performed with an initial denaturation at $94^{\circ} \mathrm{C}$ for $5 \mathrm{~min}$, followed by 30 cycles of $94^{\circ} \mathrm{C}$ for 1 min, $55^{\circ} \mathrm{C}$ for $45 \mathrm{sec}$ and $72^{\circ} \mathrm{C}$ for $45 \mathrm{sec}$ and a final extension of $72{ }^{\circ} \mathrm{C}$ for $10 \mathrm{~min}$.

The integrity of DNA was checked on $0.8 \%$ agarsose gels for genomic DNA and 1.5 to $2 \%$ agarose gels for PCR amplicons. Amplified products were sequenced with respective primers using Sanger sequencing methodology at Scigenom, Cochin, India. Sequences were submitted to NCBI Gene Bank data base and accession numbers were obtained. 


\section{Results and Discussion}

Twelve bacterial isolates were obtained from the rhizospheric soil of $T$. wallichiana, the bacterial isolates showed creamy, white to yellow color with variable sizes and margins on LB agar plates. The cells were mostly motile, rod shaped showing positive and negative Gram's reaction (Table 1) and were simultaneously subjected to the biochemical characterization for various carbohydrate utilizing tests, out of which two isolates TR5 and TR7 were found to be more effective in utilizing carbohydrate sources (Table 2).

All the twelve isolates were then screened for various plant growth promoting activities which included Phosphate solubilization, production of IAA, HCN, Ammonia and Catalase activity (Table 3). The isolates TR5 and TR7 showed the development of the highest phosphate solubilizing zone and quantitatively they also produced $405 \mu \mathrm{g} / \mathrm{l}$ and $380 \mu \mathrm{g} / \mathrm{l}$ inorganic phosphate respectively and produced efficient amount of IAA with the production of $290 \mu \mathrm{g} / \mathrm{ml}$ and $272 \mu \mathrm{g} / \mathrm{ml}$ respectively. The other plant growth promoting properties like $\mathrm{HCN}$, Ammonia and Catalase activities were also shown by both isolates (Table 3).

Since the two bacterial isolates namely TR5 and TR7 were found to be efficient and potent for the various plant growth promoting activities so these two isolates were subjected for the identification as per 16S rRNA gene sequencing. The sequences obtained after PCR amplification using specific primers for bacteria were compared with the available data in the GenBank using the BLAST. On the basis of the percentage identity TR5 strain was identified as Bacillus subtilis and TR7 as Bacillus safensis (Table 4). It has been estimated that more than 100 million tons of NPK chemical fertilizers are used annually in order to increase plant yield (Chandra et al., 2010). The potential negative effect of chemical fertilizers on the global environment and the cost associated with production has led to research with the objective of replacing chemical fertilizers with bacterial inoculants isolated from rhizopsheric soil commonly referred as Plant Growth promoting rhizobacteria. PGPRs enhance the growth of plant and reduce the damage from soil borne pathogens (Kloepper et al., 1980). Inoculation with PGPR have been tried successfully in tree species like Pinus, Picea, Tsuga, Pseudotsuga and Eucalyptus (Kovaleva et al., 2015) for increase in shoot and root length (Gujanicic et al., 2012). The bacterial genera which have been frequently used in the PGPR inoculation technique are Rhizobium (Afzal and Bano, 2008), Bacillus (Orhan et al., 2006), Pseudomonas (Naiman et al., 2009), Enterobacter (Garcia et al., 2011), Serratia (Nico et al., 2012) and Pantoea (Khalimi et al., 2012).

In the present study after screening of 12 bacterial isolates two isolates were found able to produce plant growth promoting activities like Phosphate solubilization, IAA, $\mathrm{HCN}$, Ammonia production as well as catalase activity. These two bacterial strains after molecular characterization using specific primers for $16 \mathrm{~S}$ rRNA gene were identified as Bacillus subtilis and Bacillus safensis. Because of the special physiological capabilities like the formation of extremely resistant spores and production of metabolites that have antagonistic effects on other microorganisms, Bacillus spp. are found in every environment and compete desirably with other organisms within the environment (Vargas et al., 2004). Asif et al., (2012) have reported that in Himalayan Cypress seedlings various species of Bacillus enhanced the supply of plant nutrients including essential nutrients like Nitrogen, Phosphorus, Potassium. Higher biomass production in 
Scots pine and Norway spruce was found when inoculated with Bacillus megaterium, $B$. circulans, B. licheniformis, B. pumilus, B. amyloliquefaciens by Karlicic et al., (2016).

In the present study bacterial species isolated from the rhizospheric soil of Taxus wallichiana, the TR5 and TR7 showed more potential to be used as PGPR's inoculum. Asif et al., (2013) reported Bacillus subtilis with other bacterial strains producing efficient amount of phosphate helps to increase the nutrient uptake and availability to increase the growth of Blue Pine (Pinus wallichiana) seedlings under the nursery conditions. Bacillus licheniformis, Aeromonas hydrophila, Pseudomonas putida and Burkholderia cepacia rich in inorganic phosphate were observed to enhance the growth of Robinia pseudoacacia L. and Pinus sylvistris L. seedlings (Vera et al., 2015).

Indole acetic acid (IAA) is a common natural auxin and is a product of $\mathrm{L}$ tryptophan metabolism in microorganisms. Bacillus subtilis and Bacillus safensis tested in the present study were positive for IAA production which is an important PGPR and alters root architecture and upgrade plant development (Spaepen and Vanderleyden 2011).

Table.1 Morphological characteristics of rhizobacterial species isolated from Taxus wallichiana

\begin{tabular}{|c|c|c|c|c|c|}
\hline Isolate & Colony size & Colony color & Cell motility & Cell Shape & Gram Reaction \\
\hline TR1 & Large round & Creamy & Slowly motile & Medium rods & - \\
\hline TR2 & Small round & White & Slowly motile & Oval & + \\
\hline TR3 & Large round & Yellow & Motile & Medium rods & - \\
\hline TR4 & Medium round & Creamy & Slowly motile & Small rods & - \\
\hline TR5 & Medium wavy & Off- white & Highly motile & Small rods & + \\
\hline TR6 & Small round & Yellow & Motile & Oval & - \\
\hline TR7 & Medium round & Creamy & Highly motile & Medium rods & + \\
\hline TR8 & Large round & White & Motile & Small rods & + \\
\hline TR9 & Large round & Off-white & Slowly Motile & Oval & - \\
\hline TR10 & Small wavy & Creamy & Highly motile & Thin rods & - \\
\hline TR11 & Large round & Yellow & Motile & Thin rods & + \\
\hline TR12 & Small round & Off-White & Motile & Thin rods & - \\
\hline
\end{tabular}

Table.2 Biochemical characterization of rhizobacterial isolates

\begin{tabular}{|l|c|c|c|c|c|c|c|}
\hline Isolate & Citrate & Arginine & Sucrose & Mannitol & Glucose & Arabinose & Trehalose \\
\hline TR1 & - & - & - & + & + & - & - \\
\hline TR2 & + & - & - & - & + & + & - \\
\hline TR3 & - & - & - & + & - & - & + \\
\hline TR4 & + & - & - & - & - & - & - \\
\hline TR5 & + & + & + & + & + & + & + \\
\hline TR6 & + & + & - & - & - & - & + \\
\hline TR7 & + & + & + & + & + & + & + \\
\hline TR8 & - & - & - & - & - & + & + \\
\hline TR9 & + & + & - & - & + & - & - \\
\hline TR10 & - & - & - & - & - & + & - \\
\hline TR11 & + & + & - & - & - & + & - \\
\hline TR12 & - & - & - & + & - & - & + \\
\hline
\end{tabular}

+ shows presence; - shows absence 
Table.3 Plant growth promoting trait analysis of Rhizobacterial strains

\begin{tabular}{|l|c|c|c|c|c|}
\hline \multirow{2}{*}{ Isolate } & \multicolumn{5}{|c|}{ PGP trait analysis } \\
\cline { 2 - 6 } & $\begin{array}{c}\text { Phosphate } \\
\text { solubilization } \\
(\boldsymbol{\mu g} / \mathbf{l})\end{array}$ & $\begin{array}{c}\text { IAA production } \\
(\boldsymbol{\mu g} / \mathbf{m l})\end{array}$ & $\begin{array}{c}\text { HCN } \\
\text { production }\end{array}$ & $\begin{array}{c}\text { Ammonia } \\
\text { production }\end{array}$ & $\begin{array}{c}\text { Catalase } \\
\text { activity }\end{array}$ \\
\hline TR1 & - & - & - & - & + \\
\hline TR2 & 205 & - & - & + & + \\
\hline TR3 & 220 & - & - & - & + \\
\hline TR4 & 240 & - & + & + & + \\
\hline TR5 & $\mathbf{4 0 5}$ & $\mathbf{2 9 0}$ & + & - & - \\
\hline TR6 & - & - & + & + & + \\
\hline TR7 & $\mathbf{3 8 0}$ & $\mathbf{2 7 2}$ & - & - & - \\
\hline TR8 & 340 & - & + & - & + \\
\hline TR9 & 320 & - & - & - & - \\
\hline TR10 & - & - & - & - & - \\
\hline TR11 & - & - & - & - & + \\
\hline TR12 & 195 & - & - & - & + \\
\hline
\end{tabular}

+ shows presence; - shows absence; Data are the mean values of three replicates each and all experiments were repeated twice for confirmation of results.

Table.4 BLAST search results of isolated bacterial species

\begin{tabular}{|l|l|l|l|l|}
\hline Isolate & Name & \% Similarity & Gene bank acct. No. & Fragment size (bp) \\
\hline TR5 & B. subtilis & $99 \%$ & NR_118486.1 & 1206 \\
TR7 & B. safensis & $85 \%$ & NR 113945.1 & 1208 \\
\hline
\end{tabular}

Fig.1 Map of the study area showing study sites

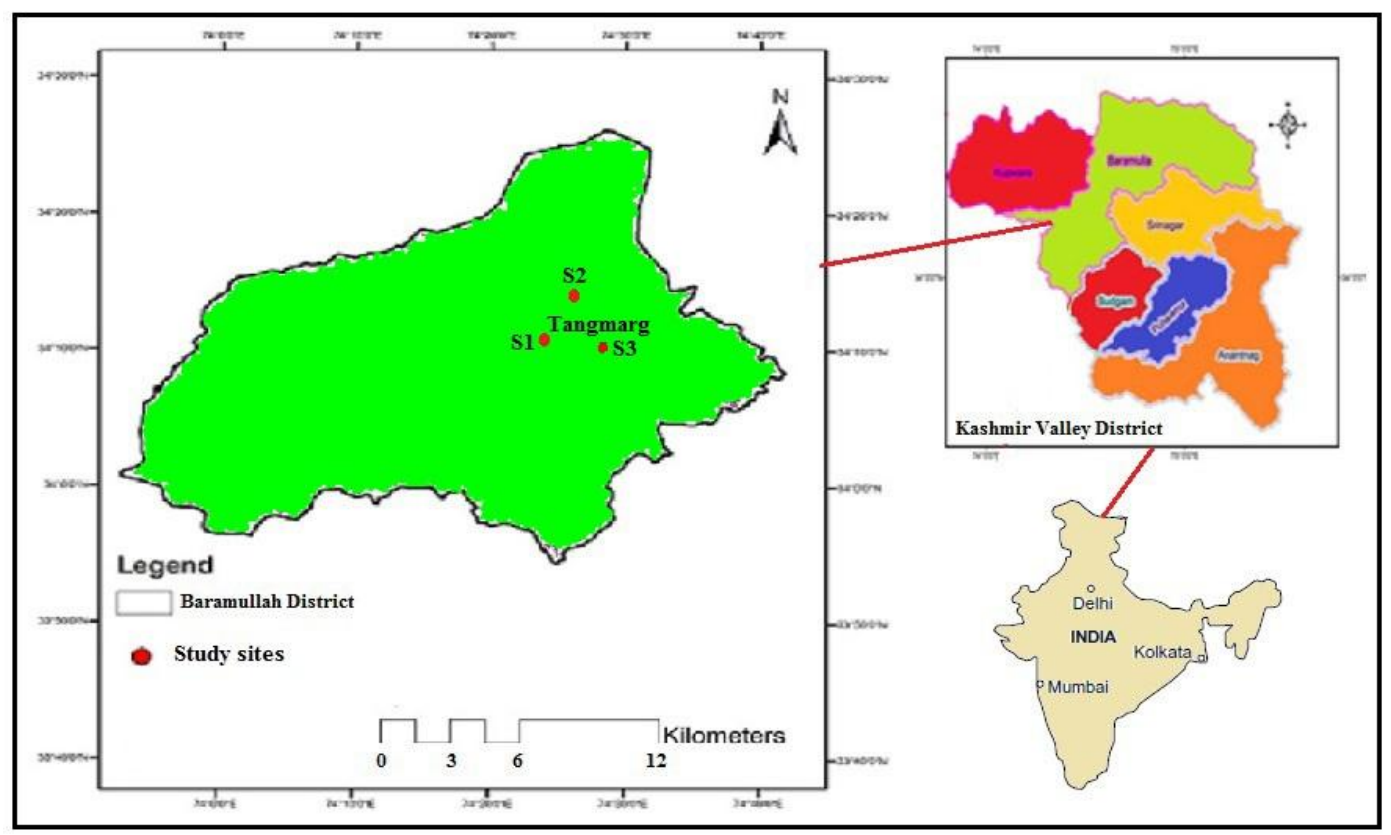


Earlier Khin et al., (2012) have reported IAA production from the Bacillus spp. and subsequent role in development of maize seedlings. Similarly, Rodge et al., (2016) have studied the bacterial isolates including Bacillus spp. for the production of IAA from the roots of Ficus religiosa. Effects of IAA producing Bacillus subtilis were also observed by Reetha et al., (2014) to enhance the germination of onion seeds.

A few bacterial species are known to produce and excrete hydrogen cyanide $(\mathrm{HCN})$, a potent inhibitor of cytochrome $c$ oxidase and several other metallo enzymes (Blumer and Haas, 2000). Hydrogen cyanide (HCN) suppresses the growth of fungal pathogens and promotes a successful competition with pathogens for nutrients or specific niches on the root surface (Cartieaux et al., 2003). Rayavarapu and Padmavathi, (2016) have used the Bacillus spp. as biofertilizer for increasing the crop yield instead of using chemical fertilizers. Earlier, Agarwal and Agarwal, (2013) reported that Bacillus species produces $\mathrm{HCN}$ from rhizospheric soils and hence indirectly influences plant growth promotion. The Bacillus spp. Isolated in present study also showed the $\mathrm{HCN}$ production so can also be used as biofertilizer.

Ammonia production by the plant growth promoting bacteria helps to influence plant growth indirectly (Geetha et al., 2014). In the present study both $B$. subtilis and $B$. safensis isolated from rhizospheric soil of T. wallichiana showed ammonia production and similar results were reported by Kumar $e t$ al., (2012) from French bean soils. Evolution of gas bubbles from the $\mathrm{H}_{2} \mathrm{O}_{2}$ solution showed positive test for the presence of catalase enzyme by the organisms. Our results are in line with Kannahi and Kowsalya, (2013) pertaining to catalase activity in Bacillus spp. However, the presence of catalase activity in Bacillus spp. has been reported by some other workers as well (Singh et al., 2015).
Current study is first of its kind in the Kashmir Himalayan region regarding the insight into the bacterial community present in rhizospheric region of this endangered forest tree. P-solubilizing and IAA are considered important PGP traits, hence in the present study we found $B$. subtilis and B. safensis efficient P-solubilizing and IAA producing bacteria among the natural population. These isolates offer potential filed application as PGP agents in Taxus wallichiana an endangered conifer of Kashmir Himalaya. Further studies should be carried out in order to get a detailed functional characterization of these Bacillus species for the practical application in natural environs.

\section{Acknowledgement}

N. Nazir was supported by $\mathrm{PhD}$ grant from University of Kashmir, Srinagar [Grant No. F (RS. Scholarship- CORD) DFBS/KU/15]. Research infrastructure was collectively provided by Centre of Research for Development (CORD) University of Kashmir and Sher-e-Kashmir University of Agricultural Sciences and Technology Kashmir (SKUAST-K). Part of the molecular analysis was performed at Scigenome Laboratory Kochin, India.

\section{References}

Afzal, A., and Bano, A. 2008. Rhizobium and phosphate solubilizing bacteria improve the yield and phosphorus uptake in wheat (Triticum aestivum). Int. J. Agri. Bio. 10, 85- 88.

Amin, M., Rakhisi, Z., and Ahmady, A.Z. 2015. Isolation and Identification of Bacillus Species From Soil and Evaluation of Their Antibacterial Properties. J. Avicenna Clin Microb Infect., 2, 232-233. 
Asif, M., Lone, S., Lone, F. A., and Hamid, A. 2013. Field performance of blue pine (Pinus wallichiana) seedlings inoculated with selected species of bio inoculants under nursery conditions. Int. J. Pharm. Bio Sci., 4, 632 - 640.

Asif, M., Zargar, M.Y., Lone, S., Lone, F.A., and Sheikh, F.A. 2012. Influence of microbial inoculants on nutrient uptake of Himalayan Cypress (Cupressus torulosa Don) seedlings under temperate nursery conditions. IJRSR. 3, 1013-1018.

Brick, J.M., Bostock, R.M., and Silversone, S.E. 1991. Rapid in situ assay for indole acetic acid production by bacteria immobilized on nitrocellulose membrane. Appl. Environ. Microbiol., 57, 535-538.

Cappuccino, J.C., and Sherman, N. 1992. In: Microbiology: A Laboratory Manual third ed. Benjamin/cummings. Pub.Co., New York. pp. 125-179.

Cardinale, B.J., Matulich, K.L., Hooper, D. U., Byrnes, J.E., Duffy, E., Gamfeldt, L., Balvanera, P., and Mary, I. O. 2011. Connor, Andrew Gonzalez, The functional role of producer diversity in ecosystems. Am. J. Botany, 98, 572592.

Cartieaux, F. P., Nussaume,L., and Robaglia, C. 2003. Tales from the underground: molecular plant-rhizobacteria interactions. Plant Cell Environ.m 26, 189-199.

Castric, P.A. 1975. Hydrogen cyanide, a secondary metabolite of Pseudomonas aeruginosa. Can J. Microbiol., 21, 613618.

Garcia, Y.E.M., Hernandez, D. J., Hernandez, C. A., Esparza, M.A. M., Cristales, M.R.B., Ramirez, L.E.F., Contreras, R.D.M., and Rojas, J.M. 2011. Growth response of maize plantlets inoculated with Enterobacter spp., as a model for alternative agriculture. Rev. Argent. Microbiol. 43, 287 - 293.

Geetha, K., Venkatesham, E., Hindumathi, A., and Bhadraiah, B. 2014. Isolation, screening and characterization of plant growth promoting bacteria and their effect on Vigna Radita (L.) R.Wilczek. Int.J.Curr.Microbiol.App.Sci. 3, 799809.

Gholami, A., Geyter, N., Pollier, J., Goormachtig, S., and Goossens, A. 2014. Natural product biosynthesis in Medicago species. Nat Prod Rep. 31, 80-356.

Jing,X., Sanders, N.J., Shi, Y., Chu,H., Classen, A. T., Zhao, K., Chen, L., Shi, Y., Jiang,Y., and He, J.S. 2015. The links between ecosystem multifunctionality and above- and belowground biodiversity are mediated by climate. Nat. Commun., 2, 8159.

Kannahi, M., and Kowsalya, M. 2013. Efficiency of plant growth promoting rhizobacteria for the enhancement of Vigna mungo growth. J. Chem. Pharm. Res., 5, 46-52.

Karlicic,V., Curguz,V.G., and Raicevic, V. 2016. The alleviation of reforestation challenges by beneficial soil microorganisms. REFORESTA, 1, 238260.

Khalimi, K., Suprapta, D.N., and Nitta, Y. 2012. Effect of Pantoeaa glomerans on growth promotion and yield of rice. $J$. Agric. Sci. Res., 2, 240 - 249.

Khin, M. L., Moe, M. M., Tar, T. W., and Aung, Z. M. 2012. Isolation of Plant Hormone (Indole-3-Acetic Acid - IAA) Producing Rhizobacteria and Study on their Effects on Maize Seedling. Eng. J., 16, 138-144.

King, E. 1959. Studies on a group of previously unclassified bacteria associated with meningitis in infants. Am. J. clin. Path., 31, 241. 
Kovaleva, V.A., Shalovylo, Y.I., Gorovik, Y.N., Lagonenko, A.L., Evtushenkov, A.N., and Gout, R.T. 2015. Bacillus pumilus - a new phytopathogen of Scots pine- Short Communication. J. Forest Sci., 61, 131-137.

Kraigher, H. 1999. Diversity of types of ectomycorrhizae on Norway spruce in Slovenia. Phyton. 39, 199-202.

Agrawal, D.P.K., and Agrawal, S. 2013. Characterization of Bacillus sp. strains isolated from rhizosphere of tomato plants (Lycopersicon esculentum) for their use as potential plant growth promoting rhizobacteria. Int. J. Agricult. Technol., 2, 406-417.

Kumar,A., Kumar, A., Devi, S., Patil,S., Payal,C., and Negi,S. 2012. Isolation, screening and characterization of bacteria from Rhizospheric soils for different plant growth promotion (PGP) activities: an in vitro study. Recent Res. Sci. Technol., 4, 01 - 05.

Majeed, A., Abbasi, M. K., Hameed,S., Imran,A., and Rahim, K. 2015. Isolation and characterization of plant growth promoting rhizobacteria from wheat rhizosphere and their effect on plant growth promotion. Frontiers Microbiol., 6, 1-10.

Naiman, A.D., Latronico, A., and Salamone, I.E.G. 2009. Inoculation of wheat with Azospirillum brasilense and Pseudomonas fluorescens: Impact on the production and culturable rhizosphere microflora. Eur. J. Soil Biol., 45, 44 - 51.

Nico, M., Ribaudo, C.M., Gori, J.I., Cantore, M.L., and Cura, J.A. 2012. Uptake of phosphate and promotion of vegetative growth in glucose exuding rice plants (Oryza sativa) inoculated with plant growth promoting bacteria. Appl. Soil Ecol., 61, 190 - 195.

Orhan, E., Esitken, A., Ercisli, S., Turan, M., and Sahin, F. 2006. Effects of plant growth promoting rhizobacteria (PGPR) on yield, growth and nutrient contents in organically growing raspberry. Sci. Hortic., 111, 38 - 43.

Parray, J.A., Jan, S., Kamili, A.N., Qadri, R.A., Egamberdieva, D., and Ahmad, P. 2015. Current Perspectives on Plant Growth-Promoting Rhizobacteria. $J$. Plant Growth Regul. Doi: 10.1007/s00344-016-9583-4.

Rahman, S., Salehin, F., Uddin, M. J., and Zahid, A. 2013. Taxus Wallichiana Zucc. (Himalayan Yew) insights on its antimicrobial and pharmacological activities. Altern. Med., 1, 3.

Rayavarapu, V.G.B., and Padmavathi, T. 2016. Bacillus sp as potential plant growth promoting rhizobacteria. IJALS. 9, 29-36.

Reetha, S., Bhuvaneswari, G., Thamizhiniyan, P., and Mycin, T. R. 2014. Isolation of indole acetic acid (IAA) producing rhizobacteria of Pseudomonas fluorescens and Bacillus subtilis and enhance growth of onion (Allim cepa. L). Int. J. Curr. Microbiol. App. Sci., 3, 568-574.

Schaad, N.W. 1992. Laboratory Guide for identification of Plant Pathogenic Bacteria. $2^{\text {nd }}$ edn. International Book Distributing Co. Lucknow. pp. 44-58.

Sharma, P., and Uniyal, P.L. 2010. Traditional knowledge and conservation of Taxus baccata in Sikkim Himalaya. NeBIO1. 1, 55-59.

Shrestha, U.B., Gautam, S., and Bawa, K.S. 2012. Widespread climate change in the Himalayas and associated changes in local ecosystems. PLoS ONE. 7. E36741

Spaepen, S., and Vanderleyden, J. 2011. Auxin and plant-microbe interactions. Cold Spring Harb Perspect Biol., 3: 1438.

Thomas, P. 2011. A review of the distribution and conservation status of Taxus in the 
Himalaya, China and Southeast Asia. Spanish J. Rural Stud., 2, 35-42.

Singh, N., Yadav, A., and Varma, A. 2015. Effect of plant growth promoting activity of rhizobacteria on Cluster bean (Cyamopsis tetragonoloba L.) plant growth and biochemical constituents. Int. J. Curr. Microbial. App. Sci. 4, 1071-1082.

Blumer, C., and Haas, D. 2000. Mechanism, regulation, and ecological role of bacterial cyanide biosynthesis. Arch. Microbial., 173, 170-177.

Vera, K., Danka, R., Jelena, J.P., Vesna, G.C., Dragan, K., and Vera, R. 2015. Inoculation of Robina pseudocacia L. and Pinus sylvestris L. seedlings with plant growth promoting bacteria causes increased growth in coal mine over burden proceedings. International Conference Reforestation Challenges. Pp. 18.

Sujatha, P., Kumar, B. N., and Kalarani, V. 2012. Isolation, characterization and molecular identification of bacteria from tannery effluent using 16S rRNA sequencing. Current Biotica, 6, 198207.

Bergey, D.H., Krieg, N.R., and Holt, J.G. 1986. Bergey's manual of systematic bacteriology, Williams and Wilkins, Baltimore, MD.

Chandra, S., Bandopadhyay, R., Kumar, V., and Chandra, R. 2010. Acclimatization of tissue cultured plantlets from laboratory to land. Biotechnol. Letters, 32, 1199-1205.

\section{How to cite this article:}

Nazish Nazir, Azra N. Kamili, M.Y. Zargar, Imran Khan, Durdana Shah, Sumira Tyub and Rubiya Dar. 2017. Studies on Bacillus sp, As an Efficient Plant Growth Promoting Rhizobacteria from Taxus wallichiana Zucc. an Endangered Conifer of Kashmir Himalaya. Int.J.Curr.Microbiol.App.Sci. 6(7): 41-50. doi: https://doi.org/10.20546/ijcmas.2017.607.006 